\title{
TRACING EARLY MARITIME SOUTHEAST ASIA THROUGH ARCHAEOLOGICAL ELEMENTS AND BENGAL'S CONTACT (400 BCE - 800 CE)
}

\author{
Sharmin Akhtar ${ }^{1 *} \&$ Hanizah Idris ${ }^{2 * *}$ \\ *First author, ${ }^{* *}$ Corresponding author \\ 1,2Department of Southeast Asia, Faculty of Arts and Social Sciences \\ University of Malaya, Kuala Lumpur, Malaysia \\ ${ }^{1}$ Department of History, University of Dhaka, \\ Bangladesh \\ (sharmin_history@du.ac.bd, wafa@um.edu.my) \\ DOI: https://doi.org/10.22452/jati.vol25no1.3
}

\begin{abstract}
Some archaeological evidence from early Bengal (the eastern coastal region of India) found in the different sites of the mainland and maritime Southeast Asia is the vital source for grasping the historical study of the immense process of 'Indianisation.' The valuable archaeological elements are Northern Black Polished Wares, Rouletted Wares, Beads, Seals with Kharoshti-Brahmi scripts, prove of most elegant clothes and the concept of Temple Architecture from Bengal. This article is an endeavour to expose these elements to demonstrate the Bengal's connection behind the 'Indianisation' process. In the initial stage (400 $\mathrm{BCE}$ to $800 \mathrm{CE}$ ) of 'Indianisation,' Bengal kept a vital role in this massive course along with other Indian regions (Tamil Nadu, Arikamedu, Uttar Pradesh, Orissa). This issue has drawn the attention of scholars from the last few generations. In the ancient period, there were some direct maritime trade routes from Bengal to the Southeast Asian region. Traders from other parts of India also used the ports of Bengal on the way towards Southeast Asia because of its strategic location. Some striking indications may come out from the study that will specify the role of Bengal behind the 'Indianisation' process. This study followed the qualitative method with historical research that focuses on the archaeological findings, ancient literature, and secondary documents.
\end{abstract}

Keywords: Bengal, Southeast Asia, Indianisation, trade, archaeological elements 


\section{Introduction}

'Indianisation' is a significant term for understanding the extensive connection and migration of the Indian people in ancient Southeast Asia. In this interaction, Bengal is also actively connected. It is essential to note that from the early historical period, there was an affinity created by the trade and cultural connection between these two regions. This relation proves the sequent interaction by the archaeological remains originated in Bengal found from the various areas of Southeast Asia. The archaeological elements found there are some seals and potteries with the Kharoshtri-Brahmi scripts, Buddhagupta's inscription, Northern Black Polished Wares, Rouletted Wares, Beads, evidence of most elegant clothes and the concept of temple architecture. It is worthless to quote that the paucity of sources is a common concern in reconstructing the history of the ancient period, and the attempt to explore this is also not the exception. Nevertheless, by analysing and cross-examining the literary sources, archaeological findings, and secondary documents, it is not impossible to proceed.

In ancient period, Bengal's territory covered present Bangladesh and the West Bengal of India. This geographical boundary lingered up to the partition of India in 1947. Bengal was divided into some geographical entities (Janapadas) or the ancient Indian township, such as Vanga, Samatata, Harikela, Vangala, Gauda, Radha, Pundra, Varendra, Suhmma. The period covered in this essay is 400 BCE to 800 C.E. that comprised the age of Maurya, Gupta, and Pala rule in the history of ancient Bengal. However, it is essential to note that 'Gangetic Valley' was a core area of Bengal that frequently referred to in this paper. This area defined by B. N. Mukherjee (1987) as follows: "[T]he parts of lower West Bengal (including its littoral area) and western sections of coastal Bangladesh were included in the early centuries of Christian Era in a country called Ganges (Ganga) in foreign sources, and Vanga in Indian text."

It is also essential to delineate the regions included in Southeast Asia in ancient times. Some ancient townships were Takkola, Ban-Don Ta Phet, Khao Sam Keo, Oc-Eo, Kedah, Prambanan, and Srivijaya. Scholars used the terms 'Greater India' or 'Further India' or 'India beyond the Ganges' to refer the whole. In modern times, areas included in this territory are Malaysia, Indonesia, Thailand, Vietnam, Cambodia, Myanmar, Philippine, Laos. There are considerable similarities since the early period in terms of language, religion, nature of life, and beliefs in these countries due to their geographical position. Southeast Asia, based on its location between the south of China and east of India, is also an important strategic location for maritime trade. Bengal's ruins 
mostly found from the countries like Vietnam, Malaysia, Indonesia, and Thailand.

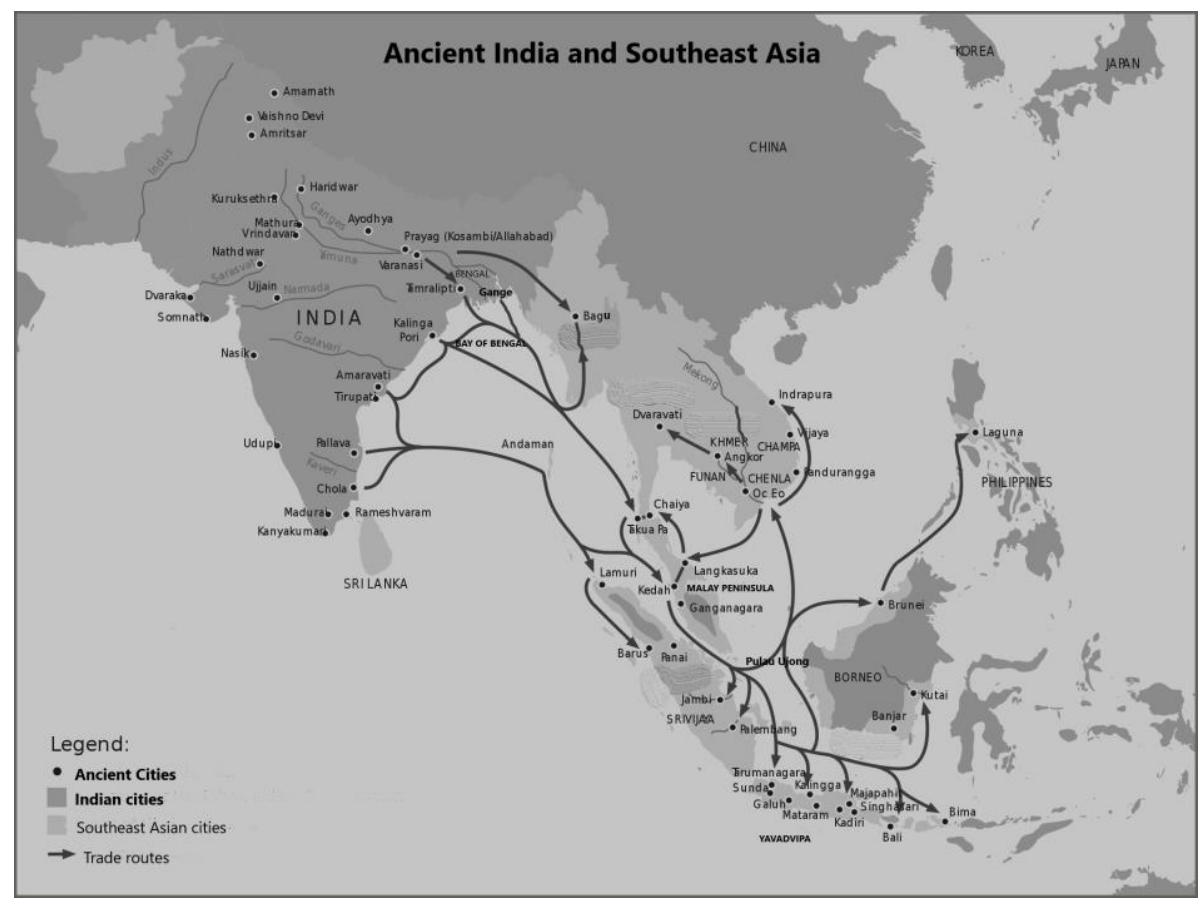

Figure 1: Ancient cities of India and Southeast Asia, and trade routes (Source: Adapted from 'Expansion of Hinduism in Southeast Asia' [25 May 2015] by the authors.)

It is worthless to mention that 'Indianisation' is a domineering academic discourse in the field of ancient Southeast Asian History. From the early time, Indian traders originally from Northwest India, later from eastern coast (Bengal) of India and South India, sailed through the Indian Ocean and the Bay of Bengal to the distant lands of various regions of Southeast Asia to build a bilateral trade relationship. Indian people frequently travelled to this region and started to live here, which gradually increased the influence of Indian culture and trade since before the Christian era. Later the political kingship steadily developed in the ancient entities of Southeast Asia. As a result, there perceived an organised cultural expansion that stood on the Indian conception of royalty and characterised by Hindu-Buddhist cults. Indian people believed in the mythology of Purans that demonstrated through the Sanskrit language in this region, which may call 'Sanskritisation' as well (Coedes, 1968, pp. 15-16). In such a way, 
various Indianised states built from the early days that influenced the overall life of the Inhabitants of Southeast Asia profoundly.

As a result, various ancient Southeast Asian territories took the Indian names. These are Suvarnadwipa (Malay Peninsula), Balidwipa (Bali), Karpuradwipa (Borneo, land of Camphor), Indradwipa (Mayanmar), Yavawipa (Java), Kataha (Kedha), Srivijaya (Sumatra), Ayudhya (Siam or Thailand). In ancient Indian texts, Ramayana and Kathasaritsagar mentioned the Malay Peninsula as Suvarnadwipa. In the same way, Arthasastra of Kautilya and Milinda-Panha identified this area as Suvarnabhumi. Thus, it is clear that most of the regions of Southeast Asia are integrated with Indian culture due to assimilation often called "osmosis" (Coedes, 1968, p. 16), through the process of gradual or unconscious assimilation of ideas and knowledge.

As an integral part of India, Bengal was a significant entity for facilitating this assimilation and expansion through its geographical location. Since Bengal situated on the east coast of India and the Bay of Bengal, it was one of the maritime trade routes of India for voyaging towards South East Asia. It is necessary to say, at that time Bengal was a wealthy geopolitical entity under the ancient Indian rule. It had two international ports; the Tamralipti and Gange, as well as many other internal ports with the connectivity of rivers and Bay of Bengal. Ptolemy's Geography, Periplus of the Erythrean Sea, also mentioned the importance of these two port's activities concerning the commercial and cultural relationship with Southeast Asian regions. They also played a vital role in Indian connection with the global economy from third or fourth century BCE that scholars sometimes mentioned this Indian shifting of commercial and cultural purpose as "look towards east" policy (Sen \& Kayal, 2007). In such a way, the ancient Indian globalisation process mostly controlled by Bengal, and Bengal was not only at the pioneering position but also continued to reach the peak of the commercial sector of India in the early period.

Hence, it is essential to explain some other particular factors that enriched the Bengal and become the driving force behind the 'Indianisation' process. Firstly, Bengal is a Deltaic region and a resourceful alluvial plain (especially Ganges Valley) from the ancient period to the current days. Secondly, the geographical position of Bengal covered a frontier zone in the Indian geographic entity situated between India and Southeast Asia. Thirdly, Indian communication from Bengal to ancient Southeast Asian regions was accessible because of the maritime route through the Bay of Bengal, and it was a comparatively short distance. Fourthly, the two international ports (Tamralipti and Chandraketugarh) were influential at that time, and Tamralipti used as a 
transit port for the trading activity of the Indian subcontinent towards Southeast Asia (Tripati, 2011).

\section{Problem Statement and Research Objectives}

Bengal's key mechanism behind 'Indianisation' is merely discussed in scholarly writings. Regarding this issue, they have principally emphasised on the accessible trade route from Bengal that has also highlighted the Bengal's prominence. Moreover, India was a well-established political entity, and it had wide-ranging geographical familiarity, whereas Bengal was only a part of this region.

The objectives of this study are to identify how the archaeological findings are related to Bengal and to what extent Bengal had the role behind 'Indianisation' that articulated by the obtained artefacts. Hence, this study aims to discuss the penetration of cultural norms and trading items of Bengal in the initial stage (400 BCE to $800 \mathrm{CE}$ ) and to identify the role of Bengal as the factor behind this process.

\section{Literature Review and Theoretical Framework}

Indian contact with Southeast Asia in the early period got immense attention from the scholars. They have written piles of related articles and books as well. Regarding the direct connection of Bengal based on archaeological findings failed to draw attention in many cases and merely pictured in their writings. Most of the scholars mentioned the role of Bengal but not by referring the archaeological materials in their writings in terms of demonstrating the Indian connection with Southeast Asia in the early period. However, the following are some specific literature that possesses the worth of recitation.

Among the scholarly writings, The Indianized State of Southeast Asia, written by G. Coedes (1968) is a pioneer work. In this book, the author explained the term 'Indianisation,' the period 'Indianisation' happened, areas covered in this process, as well as its impact on the socio-cultural life of Southeast Asia. The author emphasised the beginning of the political contact and Indianised state formation in the later period, mainly with little mentioning of the previous cultural connection that happened before the Christian era. However, Bengal's role in this process envisaged occasionally, and even the issues of Bengal's archaeological elements failed to get its place. History of Early Bengal in Regional Perspectives (up to c. 1200 CE) (Vol. I \& II) (Chowdhury \& Chakrabarti, 2018) is another very recent publication recounted the issues of the connectivity between Bengal and Southeast Asia. It proves the scholar authorships in terms of 
resourceful narration on Bengal's connection with the Southeast Asian region but merely denoted the Bengal's artefacts found in Southeast Asia.

A History of Southeast Asia (Hall, D. G., 1966) covered Southeast Asian history from early time to the contemporary period; only the first few chapters cover the historical issues of the ancient period. Here, the author discussed the Indian influence in Southeast Asia. More discussion found on the early Funan, Srivijaya, and Java, but other ancient cities of Southeast Asia did not get the attention. Southeast Asia: An Introductory History (Osborne, 2013) is also an essential contribution but narrated especially the Srivijaya's connection with ancient India. Two worth depending texts for getting the ancient Bengal's contact with Southeast Asia are A History of Early Southeast Asia: Maritime Trade and Societal Development 100-1500 (Hall K. R., 2011) and Maritime Trade and State Development in Early Southeast Asia (Hall K. R., 1985). In these academic books, the author described the various aspects of the maritime trade connection of Southeast Asian regions, including India, that sometimes recited the Bengal presence along with India.

To understand the structural features and knowledge of religious architecture, archaeological remains of Bengal, are the indication of contact between Bengal and Southeast Asia in the ancient period. Some significant writings of Enamul Haque (2001, 2003), Harunur Rashid (2008) and A. B. M. Husain (1997), are noteworthy in this context. Additionally, A Record of Buddhist Religion as Practised in India and Malay Archipelago AD 671-695 of I-Tsing which is translated by J. Takaksu (Takasuku, 1896) is also notable for grasping the accounts of Chinese pilgrims concerning ancient India and the Malay Archipelago. This book has expressed significant information about the connection between both of these regions. Narration regarding the ancient Indian colony in Southeast Asian region, the Suvarnadvipa: Ancient Indian Colonies in the Far East of R. C. Majumder (1986) is also an authentic reference. Concerning the study and interpretation of ceramics, the publication titled $A$ Sourcebook of Indian Civilisation (Ray, 2000) is also significant. A very recent book titled Cultural and Civilisational links between India and Southeast Asia (Saran, 2018) also deserves citation in regards to different issues on historical and cultural relations between India and Southeast Asia with various new concepts of an emerging culture.

Besides, some academic articles alsojustify the reference in this study. Some of the notable works are "Kharoshti and Kharoshti-Brahmi Inscriptions in West-Bengal (India)" by Mukherjee (1990), Early Trade between India and Southeast Asia: A Link in the Development of A World Trading System by Glover (1990), "Seafaring Archaeology of the East Coast of India and Southeast Asia" by Tripati 
(2017), “'Indianization' from the Indian Point of View: 'Trade and Cultural Contacts with Southeast Asia in the Early First Millennium C.E." by Monica (1999), "The Archaeology of Bengal: Trading Networks, Cultural Identities" by H. P. Roy (2006), and "Crossing the Boundaries of the Archaeology of Sompura Mahavihara: Alternative Approaches and Propositions" by Sen, Rahman and Ahsan (2014).

In terms of the theoretical framework, this study did not follow any particular theory since the fundamental archaeology theories refer to various intellectual frameworks through which archaeologist interpret archaeological data.

\section{Methodology}

This study based on historiographic norms and followed the way historical events are narrated. As primary sources, it has focused on archaeological reports of several excavations, collected pictures of artefacts from museums, story reports, books, foreign travellers account as well as from some ancient texts. Secondary literature also used in this study. Current literature reviewed through library research. Reconstructing ancient history is indeed comparatively challenging due to its sketchy nature. Therefore, this study is portrayed by the combination of primary sources and examining secondary literature.

\section{Analysis and Findings}

\section{Archaeological Remains from Bengal Found in Southeast Asia}

The archaeological findings related to Bengal are those found in different sites in Southeast Asian regions indicating the Bengal's role behind the 'Indianisation' process are as follows;

\section{Northern Black Polished Ware}

Northern Black Polished Ware (NBPW) was a leading Bengal originated artefacts found in various archaeological sites in Southeast Asia. It is a kind of aristocratic pottery produced in the middle Ganga Plain of Bengal in a period of $700 \mathrm{BCE}$ and 100 CE. (Lal, 1984, p. 94). Highly arisen clay of Gange Plain used to produce this pottery. It sometimes moderated slightly with other ingredients and advanced techniques used for firing (Chowdhury \& Chakrabarti, 2018, p. 116). Some remarkable features of this pottery were its thin fabrication, mirror-like thin-film polish, diverse colours (jet black, brownish-black to steel blue, pink, silver, golden, brown, chocolate, violet, and deep red) and variety in core colour 
like blackish, grey and red. Considering luxury items, elites in the society and the royal houses used these potteries. It was excellent in quality and durability. The variety of these potteries were dishes, jars, spouted jars, dishes-on stands and bowls-on stands, vases, and miniature vessels that had been available in various sizes and shapes.

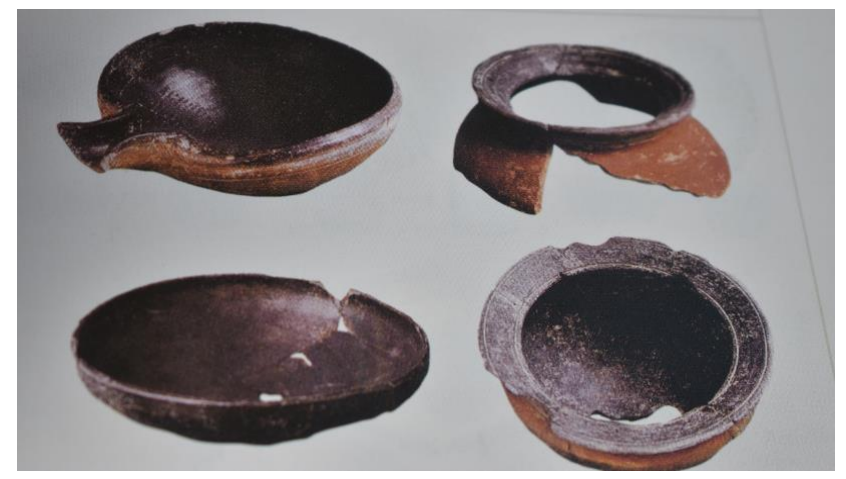

Figure 2: Impressions of Northern Black Polished Ware (NBPW) (Source: Rahman and Pathan [2012].)

This valuable commercial product exported to Southeast Asia since before the Christian era (Roy T. N., 1986; Ghose, 1989) from the Wari-Bateshwar, Gange, and Tamralipti port of ancient Bengal. Black Polished Ware found from the Tham Sua in La Un district, Kapoe in Kapoe district, Phu Khao in Suk Samran district in Ranong province, Khao Sam Kaeo in Muang district and Tham Thuay in Thung Tako district of Chumphon province in Thailand in the Southeast Asian region (Jahan, 2002, p. 209). Sometimes this pottery found along with punch-marked coins that indicate the currency-based economy (Tripati, 2017, p. 5). Moreover, Buddhism expanded to Southeast Asia from Bengal in almost the same period that also transported this prestigious element to Southeast Asia as a cultural item.

\section{Rouletted Ware}

Rouletted Ware was a kind of pottery similar to NBPW and produced in Gangeplain, including Chandraketugrah, Tamralipti, Mahasthan, and Wari-Bateshwar region of Bengal with very much ascended clay of Gange Plain in $3^{\text {rd }}$ century BCE to $3^{\text {rd }}$ century C.E. This pottery found in Kobak Kendal in Buni Cultural Sites and Cibutak of Java, Sembiran, and Pacung of Bali, Tra Kieu, Go Cam in Vietnam, Palembang in Sumatra (Schen, 2015; Ardika, 2018). The other regions of South East Asia were the Pak Chan in Kra Buri, Kapoe, Phu Khao Thong in Suk, Samran in Ranong province, Khao Sam Kaeo in Muang district and Chansen in 
Thailand (Chaisuwan \& Naiyawat, 2009; Bouvet, 2010, p. 129; Bronson \& Dales, 1978). This ware also found from Oc-Eo of Vietnam. This product also regionally transported to Sri Lanka and various areas of ancient India like Chandrabali in Karnataka, Brhmahgiri, in Andhra province.

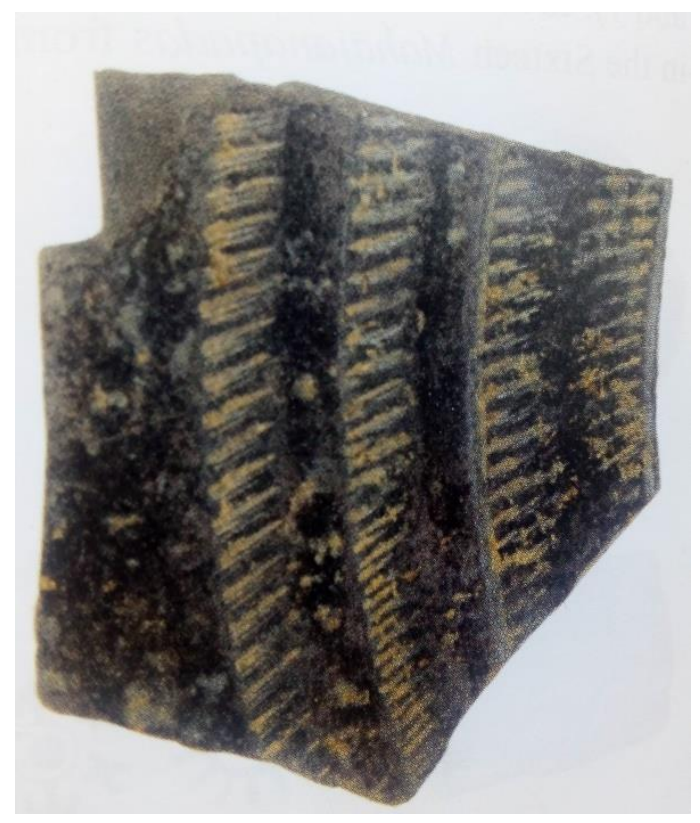

Figure 3: Impression of Roulleted Ware (Source: Chowdhury and Chakravarti [2018].)

Like NBPW, this item also closely related to Buddhism and did spread throughout Southeast Asia. It is a key ceramic of South Asia that refers some variations in terms of the design and shape such as dish style, contains bands of hollows, parallel lines, triangles, and diamonds on the interior base (Ford, Pollard, \& Coningham, 2005). This item shows the artisanship and useful skill of the local pottery manufacturers of Bengal. Therefore, this pottery item has spread the transaction and spread across Southeast Asian regions through merchants and the Buddhist culture at that period.

\section{Knobbed Ware}

Ancient Bengal's connection behind the 'Indianisation' process also reported and authenticated with the finding of Bengal's patented knobbed ware in various archaeological sites in Southeast Asia. It was a kind of pottery having a centre of the inner surface of the base stands a conical knob. This knob circumscribed by a 
series of concentric grooves or incisions. Materials used in producing this pottery are argillaceous, bronze, high tin bronze, granite, and silver. These potteries are extracted in adequate numbers, principally from Wari-Bateshwar in Bangladesh and Harinarayanpur in West Bengal of India. Moreover, later it discovered from more than a dozen archaeological sites in Bengal and Orissa and especially from Gange Valley (Glover, 1990). In India, this pottery found with little modification like the Nilgiri high-tin bronze bowl that preserved in the British Museum and the silver dish from Taxila (Marshall, 1951, p. 434).

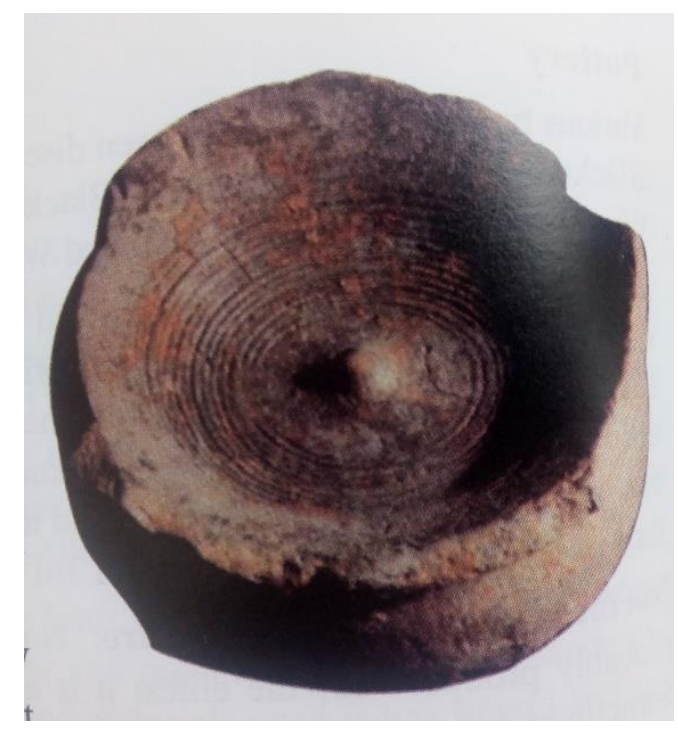

Figure 4: Knobbed Ware from Wari-Bhateshwar, Bengal

(Source: Chowdhury and Chakravarti [2018].)

In Hao Province of North Vietnam, Ban Don Ta Phet in West-Central Thailand, Khao Sam Kaeo in Southern Thailand, Ban Chiang, and Ban Nadi in northeast Thailand discovered the similar Bengal's knobbed potteries. The pottery found from Than Hao Province of North Vietnam now conserved in Gumet Museum collection, Paris. This ware also made of high tin bronze and with having a knob. Though the direct indication of usage of the Knobbed Ware is ambiguous, most of the archaeological excavators opined that this pottery principally used in burial practice. Such pottery found in Southeast Asia with the human skeleton in the archaeological sites that directly related to the Buddhist burial practice in Southeast Asia.

Therefore, Glover's statement about the connection between early Bengal and South East Asia through the Bay of Bengal authenticated by the discovery of Knobbed Ware in both the regions. This contact was, of course, in the form of the 
religious movement of Buddhism and the transaction of commercial products of the merchants which simultaneous with 'Indianisation' or happened in the age close to this immense process of spreading Indian culture in Southeast Asia in $1^{\text {st }}$ century BCE and immediate after the beginning of the Christian era (Glover, 1990).

\section{Seals with Kkaroshti-Brahmi Scripts}

Kharoshti and Kharoshti-Brahmi inscriptions are a kind of script that is a combination of the form of writing of the lower Gangetic area of West Bengal (Bhattacharyya, 1998, p. 333), which used for writing Prakrit. From the Northwest side of the Indian subcontinent, a good number of financially solvent merchants (mainly horse traders) migrated to Gangetic valley, and they introduced the Kharoshti scripts and North-Western Prakrit in Vanga (territory of ancient Bengal). It also evolved with a mixed form of scripts in this region. Usually, these scripts used and scribed on the seals, potteries, and terracotta plaques. These valuable artefacts discovered from various sites of Southeast Asia like Thailand, Vietnam, Bali, by the archaeological excavation that interestingly related to the horse trade occurred between India and Southeast Asia as well as China in the period of fourth and fifth century AD.

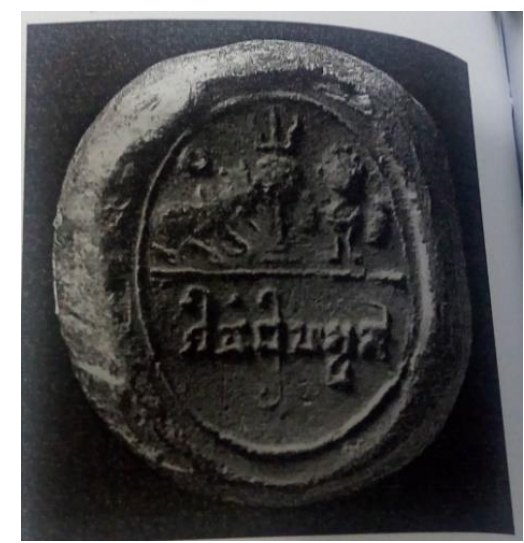

Figure 5: Bengal's Seal Impression from U Thong, Thailand (Source: Saran [2018].)

The merchants-family chose Gangetic Valley because Gange was an important international port and enriched in terms of agriculture, industrial products as well as the local artisanship of the artisan class. Reasons behind this Valley's flourishing were alluvial plain and comparatively easy riverine communication for long-distance travelling. Additionally, the second 
urbanisation phase of ancient India occurred in Bengal by the orbit of Gangetic Valley. As a result, it established as the emporium of geopolitical, socio-cultural, and economic aspects.

This script depicted on seals, potteries, terracotta plaques. Seals used as personal badges, royal, and administrative purposes. Most of the seals used as Traders identification tickets, transport documents or trader's licenses, and religious tokens. The items scribed Kharoshti and Kharoshti-Brahmi scripts, also utilised as ornaments, pieces of fine arts displaying pictures and descriptive labels. On the other hand, Chinese sources showed there were horse business connections between ancient Bengal and Southeast Asia in the fourth and fifth centuries CE. Therefore, it is clear that these two aspects have the correlation by which it can say without hesitation that in the case of horse trade, these scriptsbearing items principally used. These seals and articles, as mentioned above, were found from Chandraketugarh and Tamluk in Bengal by the excavation. Chandraketugarh was known as the production centre of these kinds of objects.

\section{Ivory Comb}

One single item of Bengal instigated artisan Ivory Comb found in the second phase of the Chansen archaeological site in Thailand that is now preserved and has been exhibiting in the National Museum of Bangkok. Ancient Bengal was a hub for Ivory Comb producing. It was famous for conceiving enormous elephants that have frequent references in the Bhatera Copper Plate of GovindaKesava and Edilpur Plate of Viswarupasena. Besides, various kinds of Ivory comb found from Chandraketughar and other sites in Bengal, since the raw materials were available because of the Bengal's prominence for Elephant.

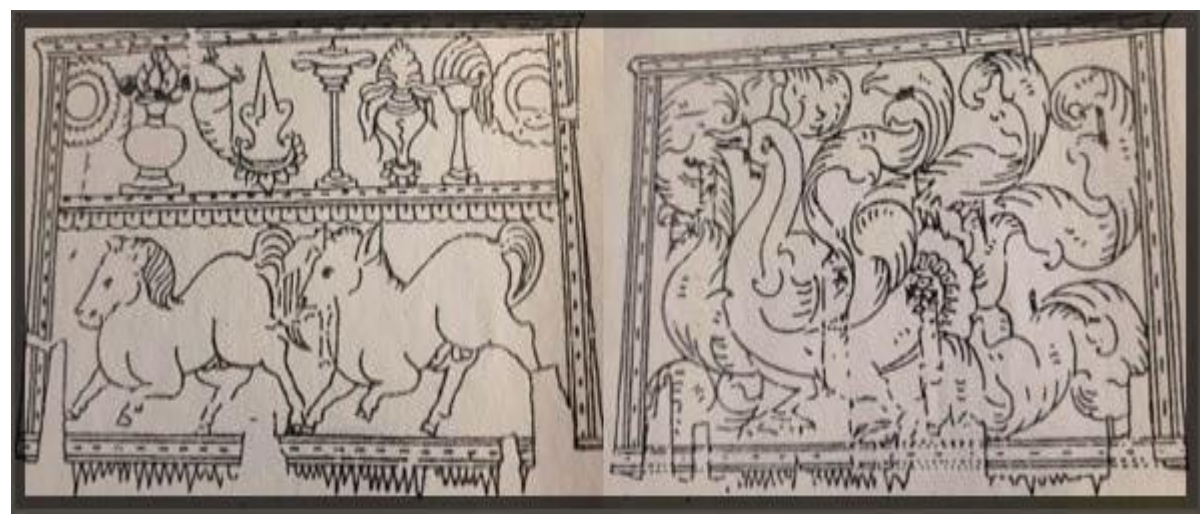

Figure 6: Ivory comb from Chansen (Phase II), Thailand (Source: Bronson and Dales [1978].) 
The period of producing this item assumed as $1^{\text {st }}$ to $4^{\text {th }}$ century C.E. that researchers narrated as the Indian style of product. As an integral part of India, Bengal can claim the patent of this product without any uncertainty (Bronson \& Dales, 1978). Another critical indication was that the producers engraved the image of horses along with goose, a Buddhist symbol, and other motifs on this comb. Most interestingly, the early Bengal's horse trade with Southeast Asia happened at the same period or in the period close to the period when artists portrayed the horses on the comb.

It is necessary to mention that engraving goose on any art elements was a tradition of Bengal's artists and mostly related to the Buddhist rituals. Moreover, the artwork of this comb also referred to as the Amravati (the east coast of India) style of reproduction that is indigenous and vibrant artisanship of India and related to the Buddha's tales narrated in Jataka, the Buddhist Literature. Therefore, the image of horses and Buddhist symbols on the comb, contemporary horse trade, Buddha's tales in Jataka concerning Amravati style of artwork, and finally discovering this unique comb item from Thailand clearly and confidently shows the Bengal's contribution.

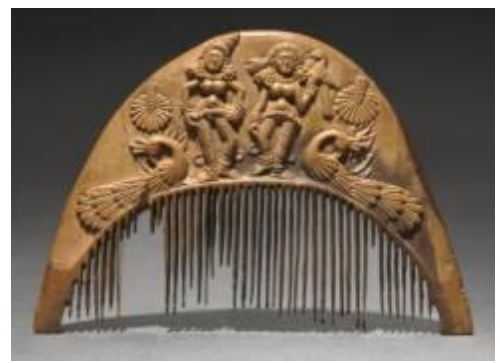

Figure 7: Ivory Comb with two Goddesses and peacocks from Chandraketugarh, Bengal

(Source: 'Comb, 2nd century BC to 1st century AD. India, Sunga Period, style of Chandraketugarh,' Artokoloro, 2019.)

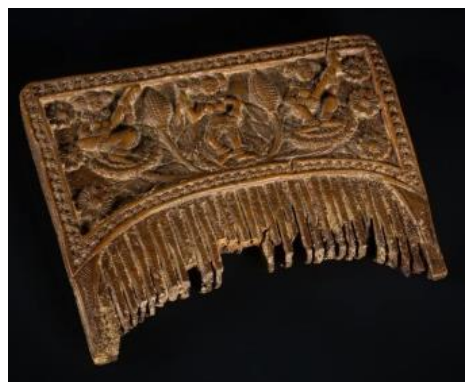

Figure 8: Ivory comb with vegetal motifs and Bengal's mythological icon 


\section{(Source: 'Indian Art A Chandraketugarh ivory comb carved with Yaksini among vegetal motifs', Arte Indiana, 2018.)}

\section{Cloth and Textile}

Ancient Bengal's prominence in producing finest-quality cloth was well blowout across the globe. Textile produced in Bengal and made of hemp, cotton, and silk as well as the cotton fragments and threads found from the burial site in Ban Don Ta Phet and Khao Sam Kaeo of Thailand (Glover \& Bellina, 2011; Glover, 1990, Tripati, 2017, p. 11) that indicate the trade of this item with Southeast Asian region. Besides, the resemble textile found in the Ban Chiang in Thailand (Srisuchat, 1996) as well.

Vanga and Pundra, the territories of ancient Bengal coined in several classical works of literature, because of the manufacturing of fine quality cotton and especially for the production of the cloth 'Muslin'. Arthasastra, a sourcebook for the history of the Maurya period, mentioned the Bengal's fabrics of diverse variety and delicacy (Islam, 1990, p. 20). It was the most exquisite quality cloth found in various designs and colours (flowered, spotted, and stripped). Periplus also referred to the production of best quality cotton cloth in ancient Gangetic country and the cannabis Sativa fibre, a kind of thread for making clothes, found in the cotton plant in South Asia that might have Bengal (Wild \& Wild, 2005; Jahan, 2002). A massive amount of coarse and fine cotton textiles (painted and printed), muslin cloth, carpets, and cushions merchandised in the different Southeast Asia countries, and the Bengal's Muslin even had the high demand in the Roman world and beyond (Bellina \& Glover, 2004).

\section{Inscription of Buddhagupta}

Stone inscription or rock art is another significant archaeological element in reconstructing ancient history. Like the rock art motif tradition observed in the Misool of Indonesia (Leihitu \& Permana, 2019), ancient India and Bengal also familiar for stone and rock art with inscriptional document. Regarding this, the Bengal originated Buddhagupta's inscription is one of the remarkable items found from Malay Peninsula.

The northern part of the province Wellesley in Malay Penninsula is a place for discovering a group of four inscriptions that inscribed on the part of a stone block in 1834 (Wheatley, 1961, p. 272). The origin of these inscriptions was ancient Indian, particularly the ancient Gauda that resembled Vanga (another ancient territory of Bengal) in the Maurya and Gupta period of ancient Bengal. The transcript of these inscriptions was the Sanskrit with Pallava scripts that were ancient Indian inscription (Nadaranjan, 2011, p. 47) in the period of fourth 
and fifth centuries. The researchers validate them as Indian, specifically the Bengal's originality of these inscriptions. They stated that among these inscriptions, one scribed with a stupa. It was bearing performance of prayer by Mahanavika Buddhagupta, who hailed from Raktamrttika (Majumder, 1986, pp. 82-83; Ray, 2000, p. 192). Hiuen Tsang, the Chinese Traveler, narrated that place as Lo-to-mo-chih (or Raktamrttika) and situated to twelve miles south of the modern Murshidabad district of West Bengal. In his description, Hiuen Tsang stated Karnasuvarna, the capital of Gauda, located nearby the monastery Raktamrttika, which identified under Gauda Janapada (territory) of Bengal.

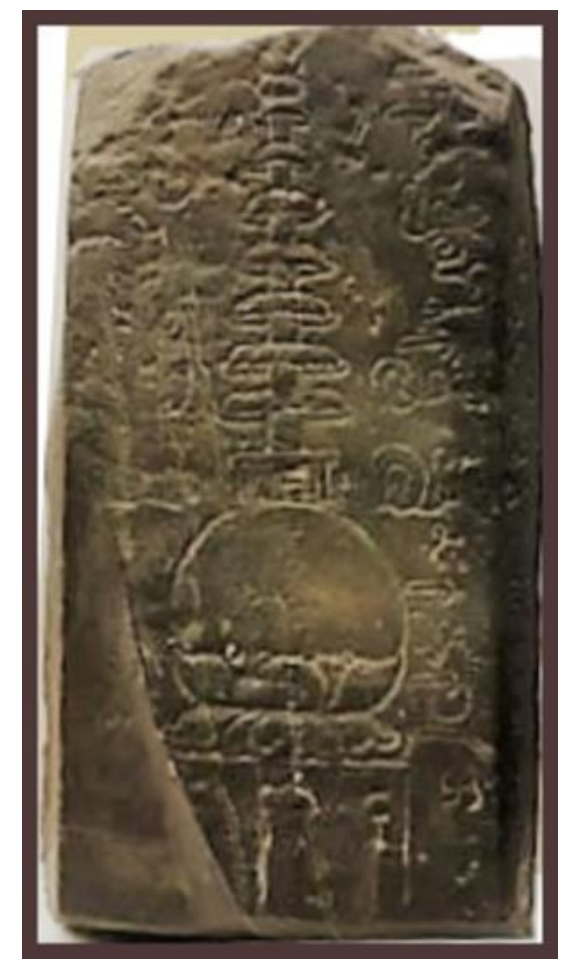

Figure 9: Buddhagupta stone inscription from Bujang Valley (Source: Collected from National Museum of Malaysia by the authors.)

Buddhagupta, the ancient Indian mariner, travelled to the province Wellesly of Malay Peninsula in the early century of the Christian era that was the high time for happening 'Indianisation' in South East Asia. Moreover, the inscription made before his return journey to Bengal. In the eve of Buddhagupta's travel to the east, a write up with wishing for successful trade voyage and protection from evil-power has noted in this stone slab as well portrait some Buddha symbols on it. Researchers stated that this was the stone- 
evidence of sea trade of Bengal with Southeast Asia in the $5^{\text {th }}$ century. Although Buddhagupta's originality regarding from Bengal questioned by levelling his inscription written in scripts from South India (Wheatley, 1961, p. 274), the above reference of determination and the Buddhist dominance in Bengal at that period accredit the Bengal's origin of Buddhagupta as well as his inscription.

\section{Beads}

The archaeological site of Wari-Bateshwar of the $4^{\text {th }}$ century BCE in Bangladesh was prominent as beads manufacturing hub. Various precious, semi-precious, well-shaped, and unevenly shaped, with and without perforation beads as well as chips and flakes made of stone like a jasper, agate, chalcedony, and amethyst, found in Wari-Bateshwar. Besides, a considerable amount of etched beads, carnelian, and agate, diverse amulet and pendants also unearthed from the site that used as ornaments and sometimes a symbol of beliefs. The large volume of production and their findings indicate the establishment of the beads industry there, and the variety, design, and colour show the artisanship of the local artists. Since Arikamedu and Orissha of India well famous in beads supplying, it sometimes assumes that the raw materials of beads for Wari came from there and manufactured beads and beads related products locally in Wari-Bateshwar.

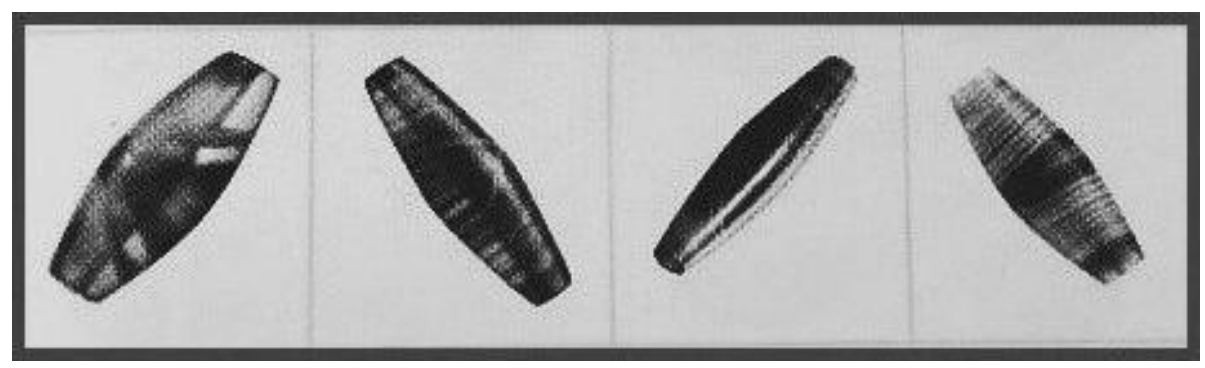

Figure 10: Impression Chalcedony

(Source: Rahman and Pathan [2012].)

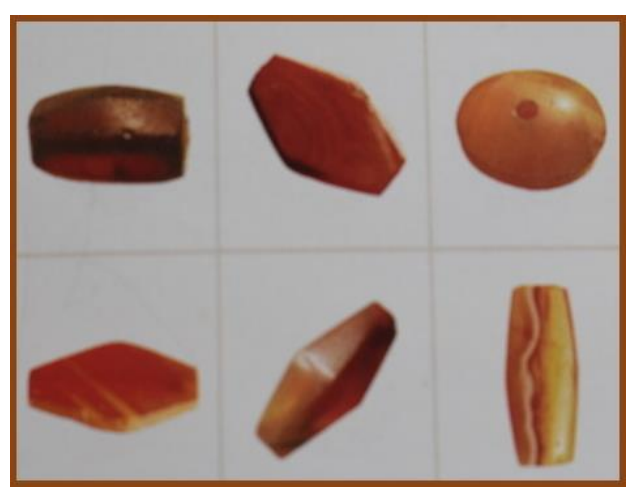


Figure 11: Carnelian beads from KSK, BDTP, Thailand

(Source: Rahman and Pathan [2012].)

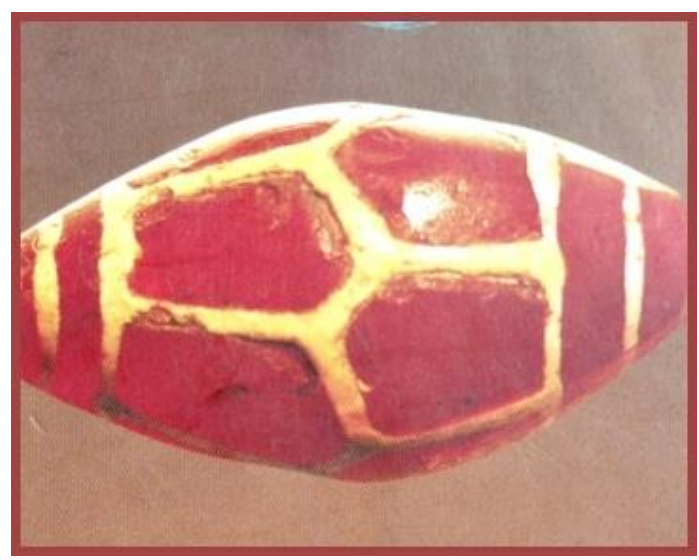

Figure 12: Etched agate beads found Wari-Bateshwar, Bengal (Source: Rahman and Pathan [2012].)

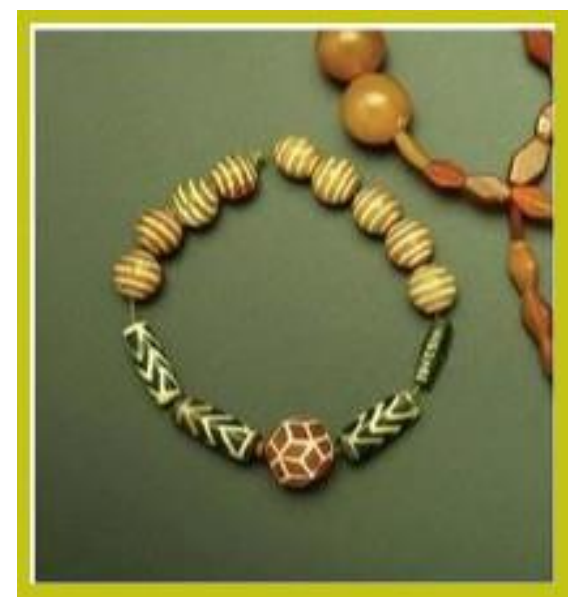

Figure 13: Etched agate beads ornament found from BDTP, Thailand (Source: National Museum, Bangkok.)

An adequate number of several stone beads found in various archaeological sites in Southeast Asia. These beads produced in ancient India and Bengal. The two most common categories of beads were oblate and spherical. This opaque black and inlaid with white stripes found in Chandraketugarh and Harinarayanpur in West Bengal and Mahasthan in Bangladesh (Rahman, 1999, p. 213) that all were under the region of ancient Bengal. A similar type of beads also found from Kausambi and Narhan of North India in Gupta period. Alike to these beads, especially opaque black round beads 
with inlaid spiral grooves, found in several sites in Southeast Asia like Prasat Muang Sing, Ban Chi Nam Lai, Kao Sam Kaeo, Khlong Thom in various sides of Thailand (Basa, 1999).

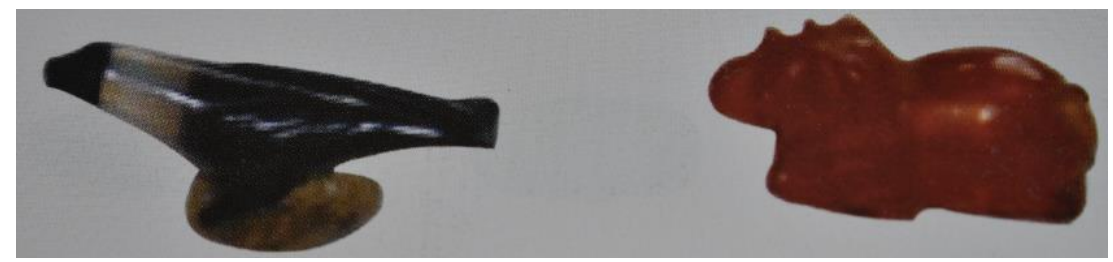

Figure 14: Impression of Semi-precious stone lockets (Source: Rahman and Pathan [2012].)

The resemble beads of opaque brownish-red and opaque orange-red with South Indian tradition (also known as Indo-pacific beads) and dateable third to second centuries found with the massive number from Ridiyagama and Mantmi in Sri Lanka, Khuan Luk Pat in Thailand, Oc-Eo in Vietnam, Kuala Selinsing in Malaysia (Francis, 1996). Precious and semi-precious glass beads found by the excavation at Sembiran (Ardika \& Bellwood, 1991) and Mutisalah (Bellina \& Glover, 2004). It also reported from North-Eastern Bali and other regions of Southeast Asia that common enough in Wari- Bateshwar, and Arikamedu (South India) that imported from India to Southeast Asia (Basa, 1992; Rahman \& Pathan, 2012).

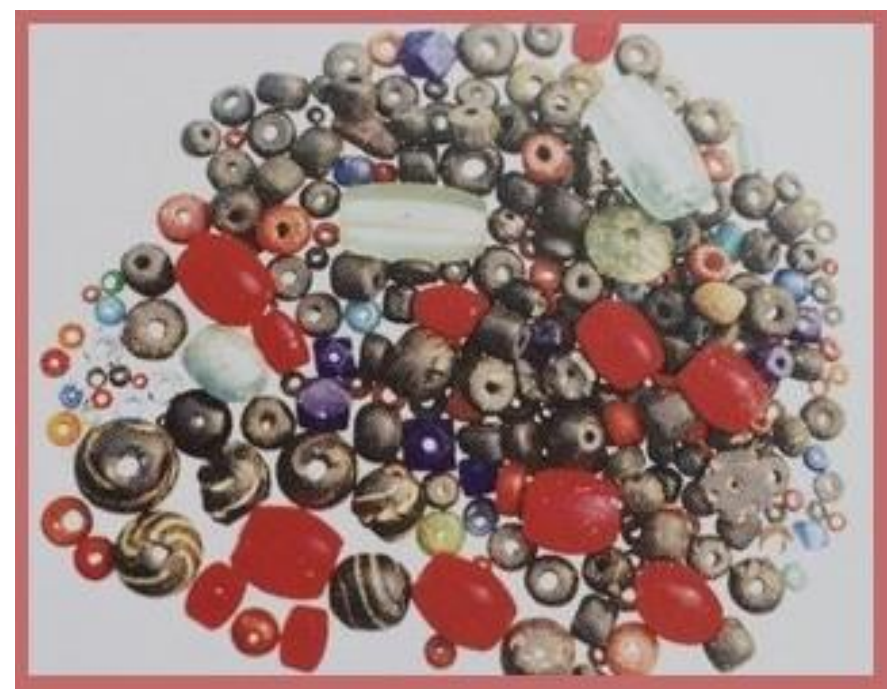

Figure 15: Glass beads from Wari-Bateshwar

(Source: Rahman and Pathan [2012].) 


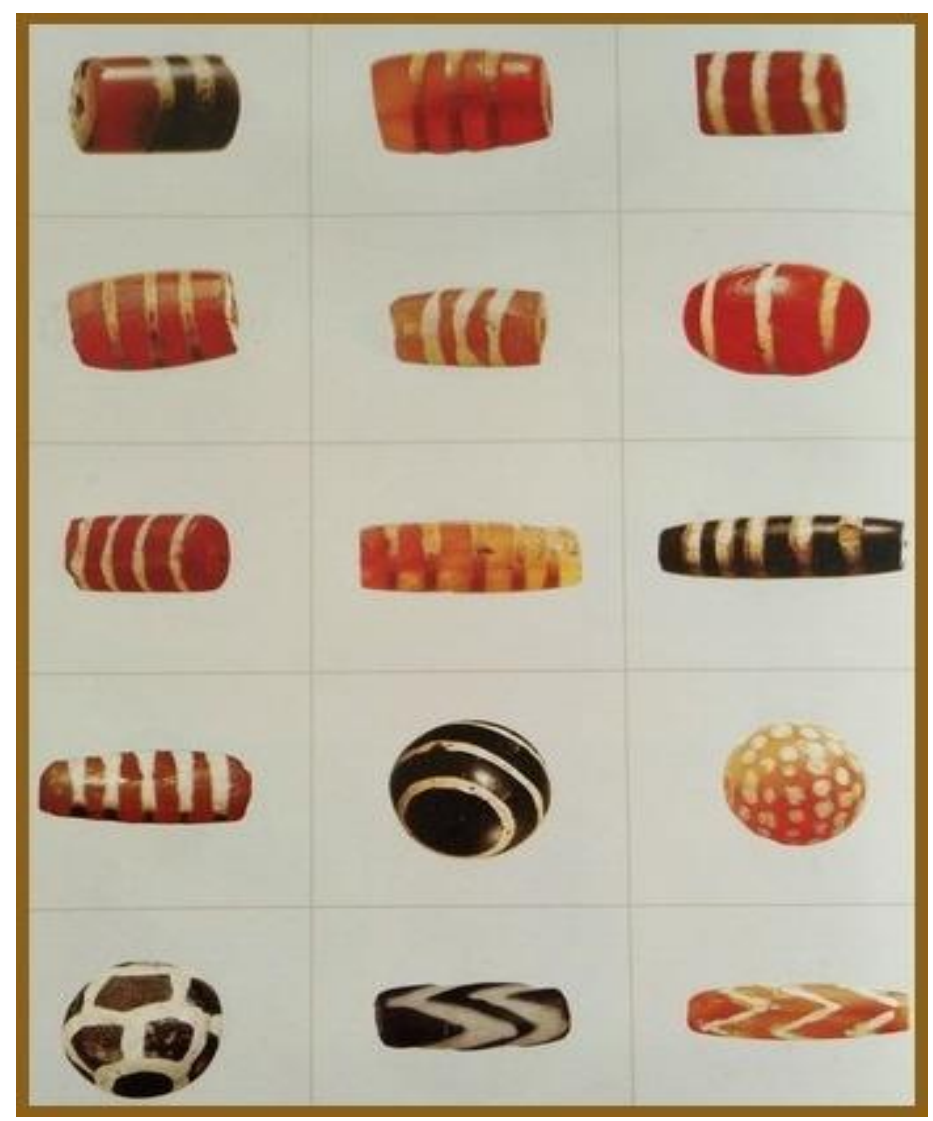

Figure 16: Etched agate from Wari-Bateshwar, Bengal (Source: Rahman and Pathan [2012].)

\section{Concepts of Architecture}

After the period of highest-level business connection, in the $7^{\text {th }}$ century CE, the Bengal's religious architectural concept became visible in Southeast Asian sites. In that time, commercial relationships played an active role in the expansion of these ideas of structural sharing. Among the monastic idea of enormous cruciform structural types likes Mahaviharas of Mainamati (in Southeast Bengal) and Paharpur (known as Shampura Vihara in the northeastern part of Bengal) in Bengal have been two most remarkable illustrations that transmitted into the concept of Southeast Asian style of architecture. The size, uniformity, arrangement, rising in receding verandas to a central temple, and the vast central yard enclosed by a line of the monastic cell is the principal features developed in Southeast Asian religious architecture from Bengal (Chakrabarti, 1992, p. 115). 
This type is associated with the famous 'Sarvatobhadra' temple type that did not appear in Hindu-Buddhist architecture of other parts of India, except Bengal.

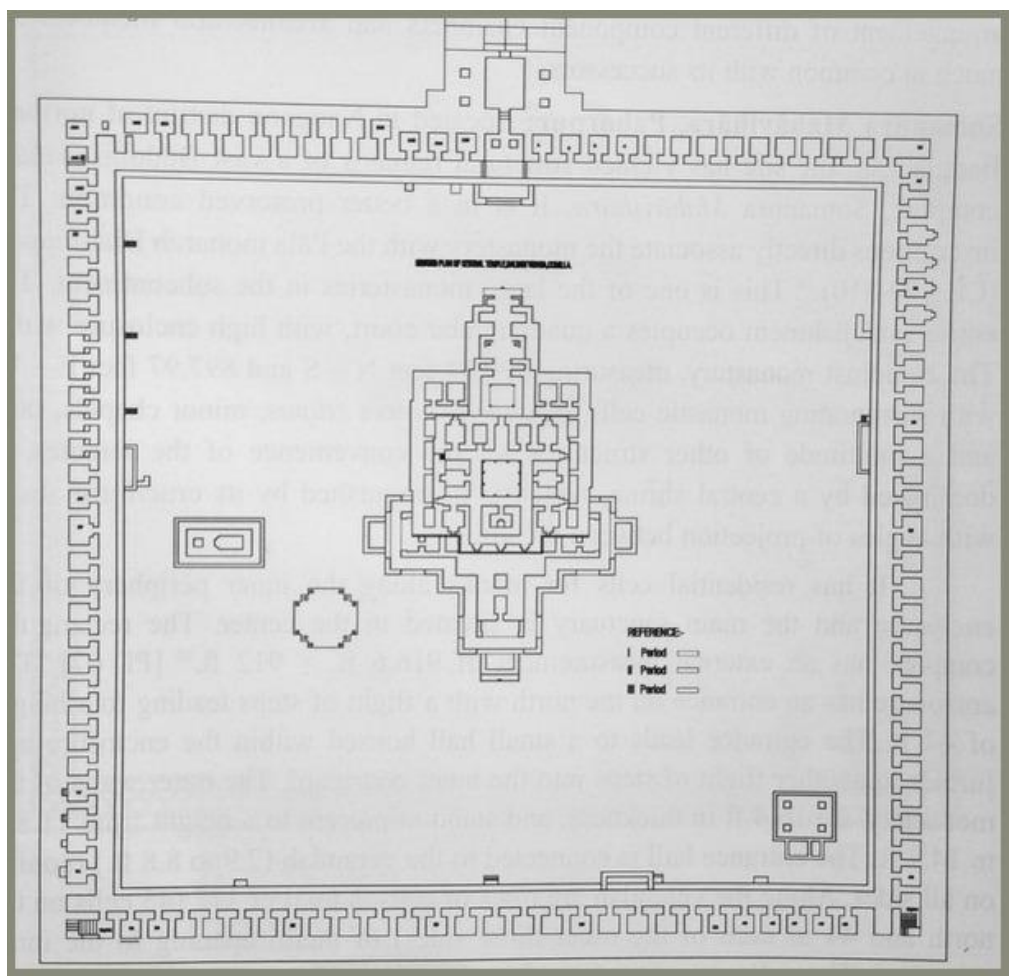

Figure 17: Layout of the Saban Vihara, Mainamati, Bengal (Source: Department of Archaeology, Government of Bangladesh.)

The earliest inception of monastic establishing happened in the first half of the $7^{\text {th }}$ century CE in Mainamati of Bengal, with the cruciform building structure of Rupban Mura Vihara, Salbon Vihara, Ananda Vihara, Bhoja Vihara (Bhuiyan, 2018). In the period of Pala dynasty such structure also built by the Pala king Dharmapala and his son Devapala in $780 \mathrm{CE}$ to $820 \mathrm{CE}$ with the massive cruciform structure of $111.5 \mathrm{~m}$ north-south by $96 \mathrm{~m}$. east-west founded in the centre (Dikshit, 1938, p. 7). It had a big courtyard encircled by a massive rectangular wall with a row of 177 monk's cell opening to a verandah (Herrmann-Pfandt, 2012). 


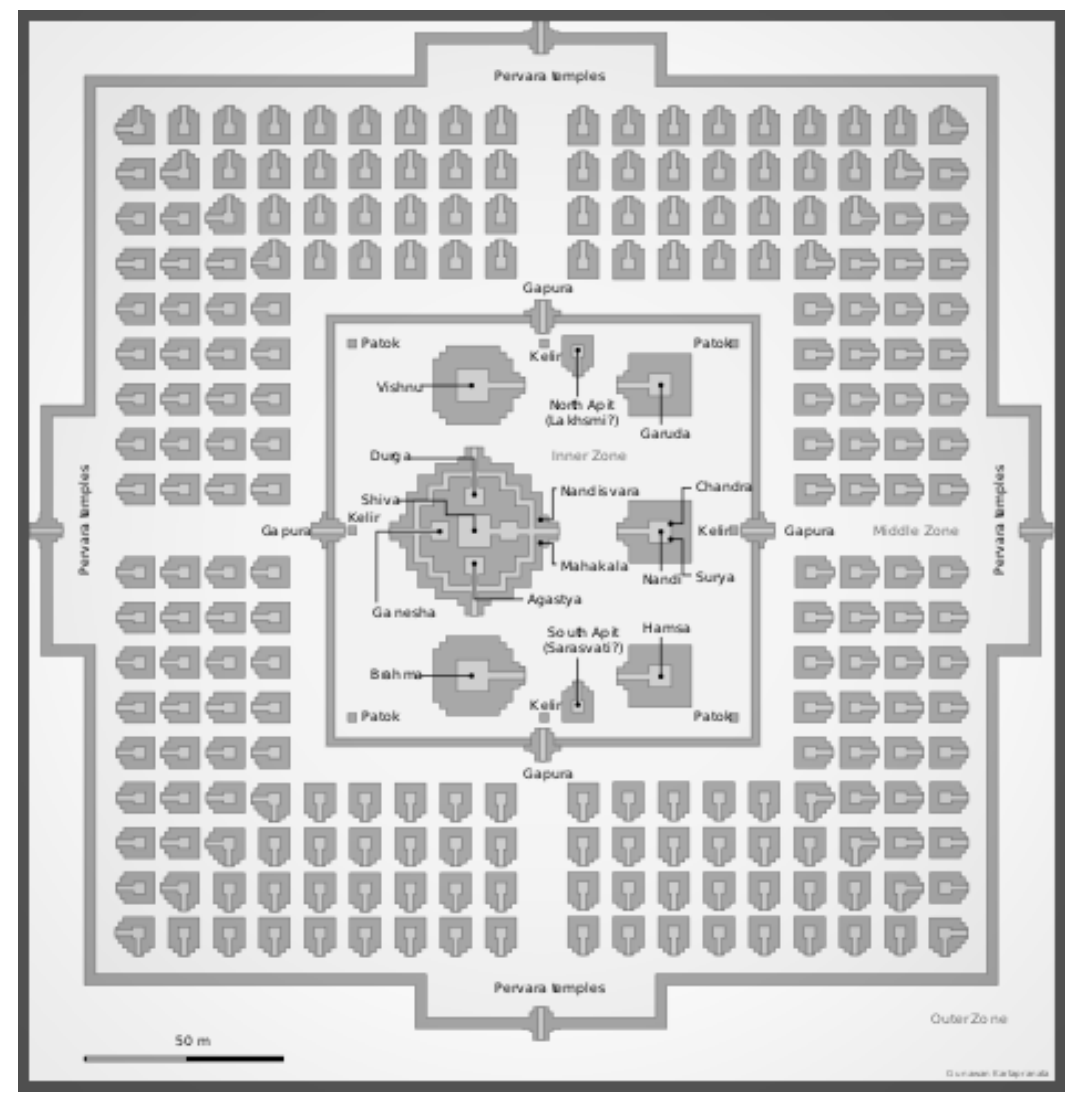

Figure 19: Layout of the temple architecture of Chandi Sevu, Java (Source: Retrieved from "Prambanan Temple Compound Map" [2016].)

Southeast Asian countries have found the same conceptual establishment as Ananda Temple at Pagan in Burma, Candi Kalsan at Prambanan in Central Java, Indonesia, that has a range of resemblance to the architectural style of the Salbon Vihara at Mainamati, and Pharpur. They also plagiarised the "Sarvatobhadra" art style from Bengal in their architecture. The ideas from Paharpur and Mainamati have considerably influenced the Candi Sevu in the $8^{\text {th }}$ century (Haque, 1998, p. 253). In the $9^{\text {th }}$ century, Borobudur temple in Java was a gigantic architecture in Southeast Asia that loaned from the concept of Bengal's religious architecture and flourished hugely. 


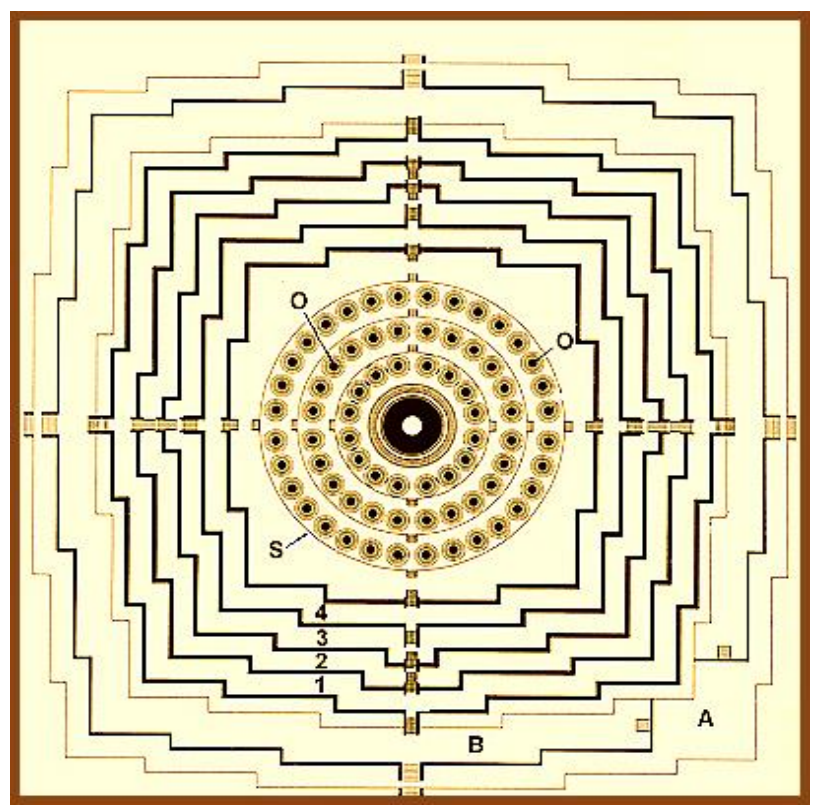

Figure 20: Layout of Borobudur Temple Architecture

(Source: Retrieved from Architecture Moleskin, Borobudur, Indonesia, 2010)

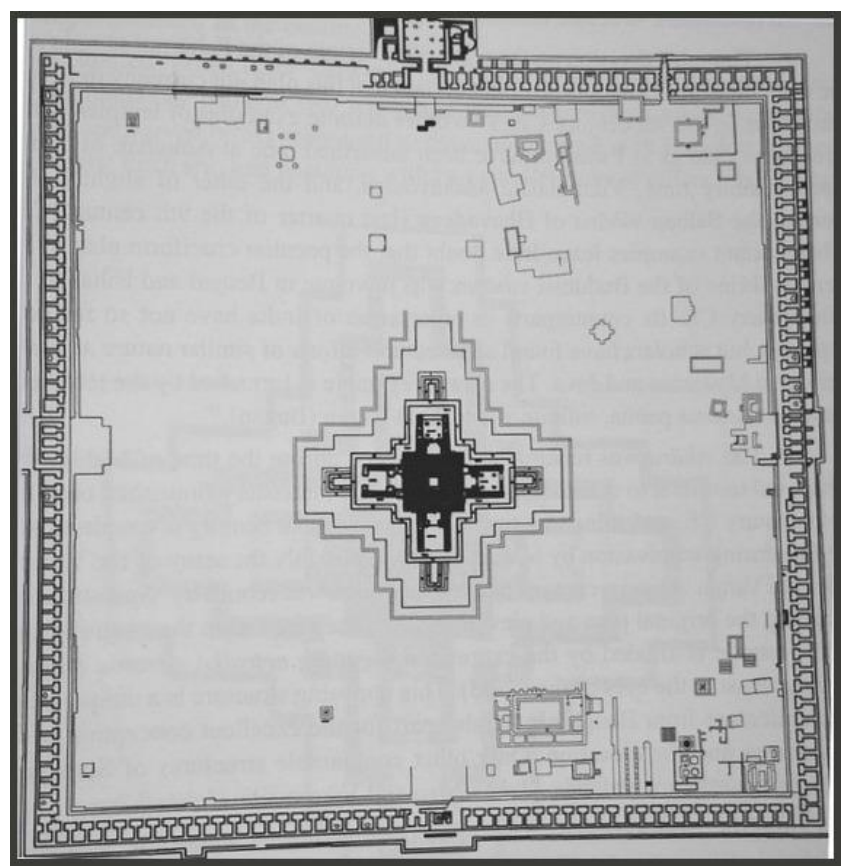

Figure 21: Layout of the temple architecture of Paharpur, Bengal (Source: Department of Archaeology, Government of Bangladesh.) 


\section{Discussion and Recommendations}

Based on the above explanation, it is clear that how archaeological findings are related to Bengal, which found from various regions of Southeast Asia with their finding places and date. In this stage, it is necessary to clarify how Bengal could act abaft the 'Indianisation' process. Explaining this issue by dividing it into two phases, the point may be more apparent and specified.

Firstly, from 400 BCE to 300 CE may identify as the first phase. In these centuries, the historical link between two regions mostly depended on trade connection and the travelling of elites and merchants (Srisuchat, 1996). For trading and travelling purpose, sometimes Bengal's merchants and aristocrats lived for a long time in Southeast Asian regions. In the initial stage, most of them associated with Hindu cults, since before Kaling War, Hindu religion dominated Northern India. Kaling kingdom located on the Indian east coast, or in Bengal. In various classical Malay-texts found the mentioning of the royal genealogies of ancient Indian kings in Southeast Asia, which show the ancestral connection of Kaling (Andaya \& Andaya, 2017, p. 17). After the Kaling War, from 260s BCE (Smith, 1962, p. 164 ), Buddhism expanded by the desire and patronisation of the Maurya Emperor Asoka in different regions of Southeast Asia. Discovering of Knobbed Ware and Roulleted Ware made explicit this thought. Most of these types of potteries found from many burials in Southeast Asia, which were related to Buddhist rituals. From that time, the travelling of Buddhist religious persons accelerated and especially the religious propagation executed in these regions. It may point here that trade was not limited to one or two areas in Southeast Asia. Virtually, Bengal's trade and Buddhism spread simultaneously in different regions. As trading items from Bengal, Pottery and Beads were in supreme position in this phase.

Secondly, the process of 'Indianisation' continued for a long time, even up to the fifteen century. This study is dealing up to $800 \mathrm{CE}$. In this instance, from $300 \mathrm{CE}$ to $800 \mathrm{CE}$ may define as the second phase. Both the Hindu and Buddhist religious influences achieved the massive scale of attention in this phase. This time, the rule of the successor of Indian kings started in early Southeast Asian regions. By their patronisation, some rituals and religious norms penetrated in the society of this region and got acceptance by the local people. In that case, Funan was the first example of these regions as an Indian state governed by leaders bearing Sanskrit titles like Raja. Hence, Indian rulers started to rule in Southeast Asia at the beginning of the third century. They also used Sanskrit as the official language of royal chancellery (Coedes, 1968, p. 40). Thus, Indian political influence with the Sanskrit language continued to enter into Southeast Asian regions. 
In that time, Bengal was a principal geopolitical province under the Gupta rule of India. As a region of the east coast of India, Bengal was able to bridge the commercial and cultural connection between India and Southeast Asia since this communication mostly happened through its nearest route of Bay of Bengal. The traders used even Bengal from other parts of India as their transit point. In this context, Tamralipti and Gange ports were the prime place for a stopover. Thus, Bengal flourished as a strategic communicating Gateway of India towards the Southeast Asian region. Consequently, the maritime connectivity between Bengal and Southeast Asian areas has also increased.

From the middle of the fourth century to the sixth century, the Ganges area of Bengal and Funan had a great connection. At the same time, King of Funan sent the ambassador to Bengal and exchanged present between these two regions (Coedes, p. 46). In terms of trade activity, Oc-Eo, Takkola, Kedah, and other ports were dominant as an emporium, where Bengal's merchants had a trustworthy position. Buddhagupta was the example of that kind of merchant. Seals also proved the frequent movement of traders from Bengal. As a trading item, in this phase, the transaction of beads continued, but potteries disappeared gradually. Ivory products, cloths, and horse trade predominantly increased from the fourth century to the seventh century. Thus, trade, political, and religious links between the two regions more developed than previous centuries.

Since the seventh-century Srivijaya, Java, Borneo also dominated by Indian power. Various Buddhist schools started to develop here, and Theraveda Buddhism took the highest position. This branch of Buddhism used the Sanskrit language that was adopted in different Southeast Asian regions. As a result, by the royal chancellery and spreading of Buddhism, some Sanskrit words entered into the local language. Such as raja (ruler), derhaka (treason), Jaya (success), negari (district, country), bahasa (language). Local people accepted this penetration. Along with the language infiltration, rulers started to build up the religious temple as same as the architectural concept from the temple architecture of Paharpur, Mainamati of Bengal, since the second half of the seventh century. In this way, in Palembang and Java temples with identical structure and style of Bengal like Chandi Sivu, Borobudur Temple were constructed.

From this discussion, the following issues from Bengal are identified that functioned as exclusive factors behind the 'Indianisation' process. 


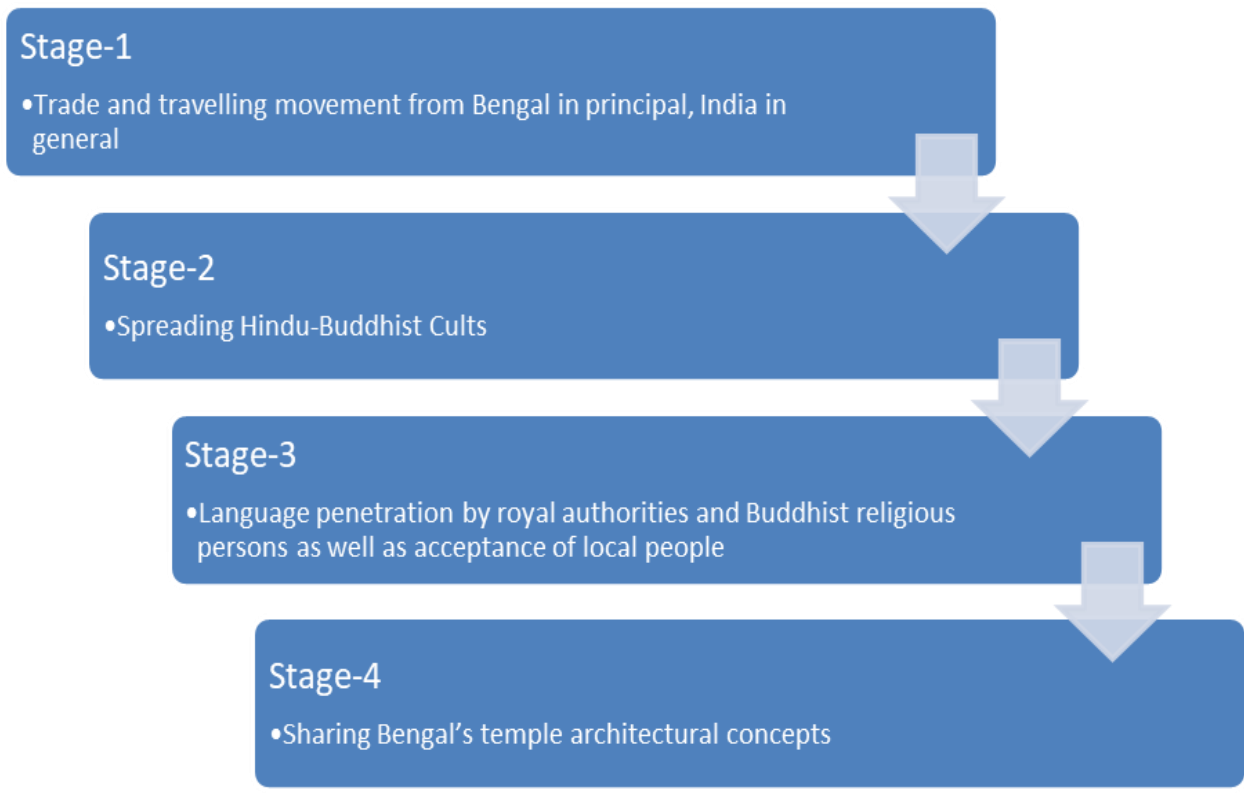

The significance of this study is that it has fulfilled the gap of presenting archaeological evidence associated with Bengal and identified the contextual factors behind the 'Indianisation.' Moreover, it has also a specific scope to do extensive research and study since it has the possibility of getting new evidence of artefacts by any further excavation.

\section{Conclusion}

In conclusion, the accessible environment and overseas innovation-receiving attitude of Southeast Asia, as well as the richness with appealing geographical location and the strategic communication route from Bengal, helped to create this contact and relation. However, by affirming the assimilation of culture and trade, the process galvanised this relation. Moreover, even the Southeast Asian region did not hesitate to amalgamate with this. Its gracious environment, the liberalism of trade, religious-tolerant approach, the captivation to the concept of architectural trend, and welcoming cultural attitude, contributed to prolonging the process of 'Indianisation.' By using and taking the opportunity of these definitive characteristics of Southeast Asia, Bengal worked as a unique factor with its wealth and advantageous geopolitical position. Thus, Bengal was actively functional and played its crucial role in this immense process of 'Indianisation' along with the other parts of India in that period. 


\section{Acknowledgements}

The authors would like to express gratitude to the University of Dhaka who supported this paper by offering the 'Bangabandhu Overseas Scholarship' and to the International Conference on Southeast Asia (ICONSEA 2019) organised by the Department of Southeast Asian Studies, University of Malaya for providing the opportunity to present it.

\section{References}

Andaya, B. W., \& Andaya, L. Y. (2017). A History of Malaysia . London: Palgrave. Ardika, I. W. (2018). Early Contacts between Bali and India. In S. Saran (Ed.), Cultural and Civilisational Links between India and Southeast Asia (pp. 19-30). New Delhi: Palgrave Macmillan.

Ardika, I. W., \& Bellwood, P. (1991). Sembiran: The Begainnings of Indian Contact with Bali. Antiquity, 65, 221-232.

Artokoloro. (2019). Comb, 2nd century BC to 1st century AD. India, Sunga Period, style of Chandraketugarh. Retrieved from Alamy: https://www.alamy.com/comb-2nd-century-bc-to-1st-century-ad-indiasunga-period-style-of-chandraketugarh-ivory

Arquitectonico, M. (2010, February 23). BOROBUDUR, INDONESIA. Retrieved from My Architectural Moleskine: http://architecturalmoleskine.blogspot.com/2010/02/borobudurindonesia.html

Basa, K. K. (1992). Early Glass Beads in India. Southeast Asian Studies, 8, 91-104.

Basa, K. K. (1999). Early Trade in Indian Perspectives on Indo-Southeast Asian Maritime Contacts (c.400 BC-AD 500). In K. S. Behera (Ed.), Maritime Heritage of India (pp. 29-71). New Delhi: Aryan Books International.

Bellina, B., \& Glover, I. (2004). The Archaeology of Early Contact with India and the Mediterranean World, from the Fourth BC to the Fourth Century AD Century. In I. C. Glover, \& P. Bellwood (Eds.), Southeast Asia: From the Pre History to History (pp. 68-89). London: Routledge.

Bhattacharyya, N. N. (1998). Encyclopaedia of Ancient Indian Culture. New Delhi: Manohar.

Bhuiyan, M. H. (2018). Mainamati. In A. M. Chowdhury, \& R. Chakravarti (Eds.), History of Bangladesh: Early Bengal in Regional Perspectives up to (c. 1200CE) (Vol. I) (pp. 263-280). Dhaka: Asiatic Society of Bangladesh. 
Bouvet, P. (2010). Study of the Indian and Indian Style Wares from Khao Sam Kaeo. In B. Bellina (Ed.), Thai-France Archaeological Mission in Upper Peninsular Thailand: An unpublished of the 2005 to 2009 Canpaigns at Khao Sam Kaeo (Chumphon) (pp. 120-152). Paris: Centre National de la Recherche Scientifique.

Bronson, B., \& Dales, G. F. (1978). Excavations at Chansen, Thailand 1968 and 1969: A Priliminary Report. Asian Perspectives, $X V, 15-46$.

Chaisuwan, B., \& Naiyawat, R. (2009). Thung Tuk: A Settlement Linking the Maritime Silk Route. Songkhla: Trio creation.

Chakrabarti, D. (1992). Ancient Bangladesh: A Study of the Archaeological Sources. Dhaka: University press Limited.

Chowdhury, A. M., \& Chakrabarti, R. (2018). History of Bangladesh: Early Bengal in regional Perspectives (Up tp c. 1200 CE) (Vol. I \& II). Dhaka: Asiatic Society of Bangladesh.

Coedes, G. (1968). The Indianized States of Southeast Asia. (W. F. Vella, Ed., \& S. B. Cowing, Trans.) Honolulu: University Press of Hawaii.

Dikshit, K. N. (1938). Excavations at Paharpur. New Delhi: ASI.

Ford, L. A., Pollard, R. A., \& Coningham, B. S. (2005). A Geochemical Investigation of the Origin of Touletted South Asian Fine Wares. Antiquity, 79(306), 909-920.

Francis, P. J. (1996). Beads, the Bead Trade and State Development in Southeast Asia. In A. Srisuchat (Ed.), Ancient Indian Traders and Cultural Contacts in Southeast Asia (pp. 139-152). Bangkok: The National Culture Commission.

Ghose, A. (1989). Encyclopedia of Indian Archaeology (Vol. II). New Delhi: Munshiram Manoharlal.

Glover, I. C. (1990). Early Trade between India and Southeast Asia: A Link in the Development of A World Trading System. Hull: Centre for South-East Asian Studies, University of Hull.

Glover, I. C., \& Bellina, B. (2011). Ban Don Ta Phet and Khao Sam Kaeo: The Earliest Indian Contacts Re-accessed. In P. Y. Manguin, A. Mani, \& G. Wade (Eds.), Early Interactions between South and Southeast Asia: Reflections on Cross-Culturao Exchange (pp. 17-46). Singapore: ISEAS.

Hall, D. G. (1966). A History of Southeast Asia. London: Macmillan.

Hall, K. R. (1985). Maritime Trade and State Development in Early Southeast Asia. Honolulu: University of Hawaii Press.

Hall, K. R. (2011). A History Early Southeast Asia: Maritime Trade Societal Development 100-1500. Plymouth: Rowman \& Littlefield Publishers. Inc.

Haque, E. (1998). Maritime Activities and the Indigenous Traditions of BoatBuilding in Ancient and Mediaeval Bengal. Bengal Art, 243-262. 
Haque, E. (2001). Exacavation at Wari-Bateshwar: A Preliminary Study. Dhaka: International Centre for Study of Bengal Art.

Haque, E. (2003). Chandraketugarh: Enigmatic Entreport of Ancient Bengal. In P. Pal, \& E. Haque (Eds.), Bengal: Sites and Sights. Mumbai: Marg Publications, pp. 17-49.

Herrmann-Pfandt, A. (2012). The Mandala Temples in Paharpur, Mainamati and Vikramsila: A New Interpretation. Bengal Art, 17, 111-134.

Husain, A. B. (Ed.). (1997). Mainamati-Devaparvata. Dhaka: Asiatic Society of Bangladesh.

Indiana, A. (2018, 12 17). Indian Art A Chandraketugarh ivory comb carved with yakshini among vegetal motifs West Bengal, Sunga dynasty, 2nd century b.C.-1st century AD. Retrieved from AuctionZip: https://www.auctionzip.com/auction-lot/Indian-Art-A-Chandraketugarhivory-comb-carved-wi_9394569AB4/\#moreAboutThisItem.

Islam, K. (1990). Aspects of Economic History of Bengal. Dhaka: Asiatic Society of Bengal.

Jahan, S. H. (2002). Early Maritime Trade Network of Bengal. Man and Environment, XXVII(1), 127-138.

Kartapranata, G. (2015, May 25). Expansion of Hinduism in Southeast Asia. Retrieved from Wikimedia Commons: https://commons.wikimedia.org/wiki/File:Hinduism_Expansion_in_Asia. svg

Kartapranata, G. (2016, March 16). Prambanan Temple Compound Map. Retrieved from Wikimedia Commons: https://commons.wikimedia.org/wiki/File:Prambanan_Temple_Compou nd_Map_en.svg

Lal, M. (1984). Settlement History and Rise of Civilisation in Ganga-Yamuna Doab (from 1500 bC to300 AD). Delhi: B. R. Publishing Corporation.

Leihitu, I, \& Permana, RCE. (2019). A Reflection of Painting Tradition and Culture of the Austronesian Based on the Rock Art in Misool, Raja Ampat, West Papua. JATI-Journal of Southeast Asian Studies. 24(1), 2019, 220-242. DOI: https://doi.org/10.22452/jati.vol24no1.9

Majumder, R. (1986). Suvarnadvipa: Ancient Indian Colonies in the Far-East (Vol. II). New Delhi: Gian publishing House.

Marshall, J. (1951). Taxila (Vol. II). Cambrige: Cambrige University Press.

Monica, L. S. (1999). 'Indianisation' from the Indian Point of View: Trade and Cultural Contact with Southeast Asia in Early First Millennium C.E. Journal of the Economic and Social History of the Orient, 42(1), 1-26. 
Mukherjee, B. N. (1987). The Territory of the Gangaridai. Indian Journal of Landscape Systems and Ecological Studies, II, 65-90.

Mukherjee, B. N. (1990). Kharoshti and Kharoshti-Brahmi Inscriptions in WestBengal (India). Indian Museum Bulletin, XXV, 9-39.

Nadaranjan, V. (2011). Bujang Valley: The Wonder that was Ancient Kedah. Sungai Petani: Dato V. Nadaranjan.

Osborne, M. (2013). Southeast Asia: An Introductory History . Crows Nest: Allen \& Unwin.

Rahman, S. M. (1999). Archaeological Investigation in Bogra Dictrict, Bangladesh (from Early Historic to Early Medieval Period). PhD Dissertation, Department of Archaeology, Deccan College Posrgraduate and Research Institute, Pune, India.

Rahman, S., \& Pathan, M. H. (2012). Wari-Bateshwar Shekorer Shondhane. Dhaka: Prothoma.

Rashid, M. H. (2008). The Early History of Southeast Bengal in the Light of Archaeological Materials. Dhaka: Itihas Academy.

Ray, N. (2000). A Source Book of Indian Civilisation . Hyderabad: Orient BlackSwan.

Roy, H. P. (2006). The Archaeology of Bengal Trading Networks, Cultural Identities. JESHO, XLIX, 68-95.

Roy, T. N. (1986). A Study of Northern Black Polished Ware Culture. New Deldi: Ramanand Vidya Bhawan .

Saran, S. (2018). Cultural And Civilisational Links Between India And Southeast Asia. New Delhi: Palgrave Macmillan.

Schen, H. (2015). Role of Ceramics in the Indian Ocean Maritime Trade during the Early Historic Period. In S. Tripati (Ed.), Maritime Contacts of the Past Deciphering Connections amongst Communities (pp. 143-181). New Delhi: Delta Book World.

Sen, R. K., \& Kayal, J. (2007). India-Bali Economic Trade: The Past and the Future. In K. C. Roy, \& S. Chatterjee (Eds.), Reading in World Development: Growth , Development and Poverty Alleviation in the Asia-Pacific (pp. 15-22). New York: Nova Science Publishers.

Sen, S., Rahman, S. A., \& Ahsan, S. (2014). Crossing the Boundaries of the Archaeology of the Sompura Mahavihara: Alternative Approaches. Pratnatattva, 20, 49-70.

Smith, V. A. (1962 ). The Early History of India. London: Oxford University press.

Srisuchat, A. (1996). Merchants, Merchandise, Markets: Archaeological Evidence in Thailand Concerning Maritime Trade Interections between Thailand and other Countries of the 16th Centuries AD. In A. Srisuchat (Ed.), 
Ancient Trade and Cultural Contacts in Southeast Asia (pp. 237-274). Bangkok: National Cultural Commission.

Takasuku, J. (1896). A Record of Buddhist Religion as Practiced in India and Malay Archipelago A.D. 671-695 by I-ting. Oxford: Clarendon.

Tripati, S. (2011). Ancient Maritime Trade of the Eastern Indian Littoral. National institute of Oceanography, 100, 1076-1086.

Tripati, S. (2017). Seafaring Archaeology of the East Coast of India and Southeast Asia. Ancient Asia, 8, 1-22.

Wheatley, P. (1961). The Golden Khersonese. KualaLumpur: University of Malaya Press.

Wild, J. P., \& Wild, F. (2005). Rome and India: Indian Cotton Textiles from Berenike, Red Sea Coast of Egypt. In R. Bernes (Ed.), Textiles in Indian Ocean Societies (pp. 11-16). London: Routledge Curzon. 
Tracing Early Maritime Southeast Asia through Archaeological Elements and Bengal's Contact (400 BCE - 800 CE)

Date Received: 2 January 2020

Date of Acceptance: 1 June 2020 